\title{
Influence of Combinations of Pesticides and Fertilizers on Aquatic Productivity
}

\author{
Ganapati Hegde, Mahesh Mandya, Sushma S. Gokarnakar, Vinodbabu N. Babu, \\ Vijayakumar N. Shivaramaiah, Sannanegunda V. Krishnamurthy* \\ Department of Environmental Science, Kuvempu University, Inana Sahyadri, India \\ Email: ${ }^{*}$ svkrishnamurthy@gmail.com
}

Received 12 February 2014; revised 13 March 2014; accepted 15 April 2014

Copyright (C) 2014 by authors and Scientific Research Publishing Inc.

This work is licensed under the Creative Commons Attribution International License (CC BY).

http://creativecommons.org/licenses/by/4.0/

(c) (i) Open Access

\begin{abstract}
We have examined the effects of environmentally realistic concentrations of widely used pesticides and fertilizers for rice paddy in Western Ghats regions of India on chlorophyll and zooplankton production using a laboratory mesocosm. Malathion $\left(100 \mu \mathrm{g} \cdot \mathrm{L}^{-1}\right)$, Cypermethrin $(25$ $\left.\mu \mathrm{g} \cdot \mathrm{L}^{-1}\right)$, Nitrate-nitrogen $\left(8 \mathrm{mg} \cdot \mathrm{L}^{-1}\right)$ and Phosphate-phosphorus $\left(8 \mathrm{mg} \cdot \mathrm{L}^{-1}\right)$ in different combinations such as pesticide-pesticide and pesticide-fertilizer were tested in fully factorial manner for a period of 42 days. Study revealed that, chlorophyll production was supported by addition of fertilizers, while combinations of fertilizers with either one or two pesticides reduce the zooplankton density and diversity rendering chlorophyll concentration more than control groups. This could indicate the reason for eutrophication of ponds located in agro-ecosystems. Single application of combinations of pesticides (in spite of presence of fertilizers) even at low concentrations can produce severe negative effects on several taxonomic groups zooplankton living in small shallow water.
\end{abstract}

\section{Keywords}

Chlorophyll Production, Zooplankton, Pesticide, Fertilizers, Combinations of Pesticides and Fertilizers

\section{Introduction}

Use of agrochemicals is ever increasing in modern agricultural practices, and they were known to contaminate agro-ecosystem, posing higher risk to non target organisms [1]-[3]. Agrochemicals of modern agriculture include variety of synthetic pesticides and fertilizers. When pesticides are applied to protect crop from pests and

*Corresponding author. 
diseases, only around $15 \%$ of the preparation hits the target and rest will be distributed into the soil, water and air; finally reach the nearby water bodies through run-off [4] [5]. These pesticides in water body can impair the structure and function of the aquatic ecosystem [6]. Thus, pesticides are a main source of contaminants in aquatic bodies of agro-ecosystem.

Pesticides reduce the zooplankton diversity and biomass of predatory insects [7]. Several species in aquatic communities are drastically affected by even very low concentration of pesticides. Mixtures of pesticides pose greater effect and even cause 99\% mortality than individual pesticides [8]. Most of the pesticides have enzyme and hormone disrupting mechanisms contributing to the decline of zooplankton, macro invertebrates and vertebrate populations in aquatic ecosystem, this can lead to the blooming of individual species (especially primary consumers) that might be detrimental [9].

Excessive loading of both phosphate and nitrogen is known to enhance the algal growth indirectly altering the aquatic community [10]. Nutrient pollution from agricultural activities causes adverse effect on the environment. Fertilizers are considered one of the main pollutants and agricultural run-off leads to contamination of streams, lakes and surface water bodies resulting in enhancement of the algal growth, richness of aquatic organisms and eutrophication. Fertilizers also have greater synergistic effects on the physiology of non-target species when combined with pesticides [11]. Even low concentrations of pesticide (0.13 to $0.46 \mathrm{mg}$ malathion $\left.\cdot \mathrm{L}^{-1}\right) \mathrm{can}$ affect the food web and predators by reducing zooplankton diversity and abundance, subsequently increasing the phytoplankton community [6]. However, level of toxicity, time of exposure, quantity of dose and persistence capacity in environment is the key factors to determine the impacts of pesticides and fertilizers on aquatic organisms and productivity [12].

Since many studies have revealed that individual effect of pesticides negatively influence on population of zooplankton, while fertilizer increase the population of phytoplankton. Many fertilizers and pesticides combinations used in the study are being used by local rice paddy growing community in agro-ecosystems of Shankaraghatta village $\left(13^{\circ} 43^{\prime} 28.90^{\prime \prime} \mathrm{N}\right.$ and $\left.75^{\circ} 40^{\prime} 36.01^{\prime \prime} \mathrm{E}\right)$ of Karnataka state in India and many small intermittent water bodies in these locality showed clear eutrophication and few lower invertebrate diversity. In the present study we have examined the effect of various environmentally realistic combinations of malathion and cypermethrin with nitrate and phosphate fertilizers on aquatic productivity.

\section{Materials and Methods}

\subsection{Experimental Design}

This 42 days experiment was conducted using laboratory mesocosm made up-off inert polyethylene containers $(100 \mathrm{~cm} \times 40 \mathrm{~cm} \times 21 \mathrm{~cm})$. We examined interactive effects of environmentally realistic concentrations of nitrate, phosphate, malathion and cypermethrin in a fully factorial experiment conducted in triplicate. In this experiment, we tested effect of combination of $100 \mu \mathrm{g} \cdot$ malathion $\cdot \mathrm{L}^{-1}$ with $8 \mathrm{mg} \cdot \mathrm{L}^{-1}$ each nitrate and phosphate, 25 $\mu \mathrm{g} \cdot$ cypermethrin $\cdot \mathrm{L}^{-1}$ with $8 \mathrm{mg} \cdot \mathrm{L}^{-1}$ each nitrate and phosphate, combination of malathion $100 \mu \mathrm{g} \cdot \mathrm{L}^{-1}$ and cypermethrin $25 \mu \mathrm{g} \cdot \mathrm{L}^{-1}$, and combinations of these two pesticides with $8 \mathrm{mg} \cdot \mathrm{L}^{-1}$ each nitrate and phosphate on chlorophyll productivity and zooplankton density and diversity in a laboratory experimental design by using a control for the purpose of comparison. Nominal concentrations of nitrate $8 \mathrm{mg} \mathrm{NO}-\mathrm{N} \mathrm{L}^{-1}$ and $8 \mathrm{mg} \mathrm{PO}_{4}-\mathrm{P} \mathrm{L}^{-1}$ were prepared using Sodium nitrate (Product No. 27855, purity 98\%, Batch No. NL151864065, Qualigens Fine Chemicals) and Potassium nitrate (Product No. 13405, purity 99.5\%, Batch No. NL537462055, Glaxon SmithKline Pharmaceuticals, India) and aged tap water. Similarly nominal concentration of malathion and cypermethrin (100 and $25 \mu \mathrm{g} \cdot \mathrm{L}^{-1}$ respectively) was prepared following [13] [14]. The malathion and cypermethrin concentrations were prepared using commercial grade malathion (AI 50\% (Reg. no.CIR 5-154(3) malathion (EC)-134, Batch no. 134; Insecticides (India) Limited, Rajasthan, India) and cypermethrin AI 25\% (Reg. no. CIR 20994/95/cypermethrin (EC)-1080, Batch no. SPP8JC43; Pioneer Pesticide Private Limited., J\&K, India) respectively.

Before starting pesticide and fertilizer treatments, $16 \mathrm{~L}$ of plankton free aged tap water inoculated with $4 \mathrm{~L}$ of pond water was taken in each container. After inoculation, each container was aerated for 30 minutes and water in the container was allowed to stabilize for 3 days. Later for each container, different pesticide combinations released. Following the treatment of agro-chemicals, at every three days, the zooplankton density and diversity was assessed by filtering $1 \mathrm{~L}$ water from each container. The zooplankton was identified up to generic level using the taxonomic keys of [15] and zooplankton density was assessed using Sedgwick-rafter cell. On every $7^{\text {th }}$ 
day until the end of the experiment, chlorophyll estimation of water in each container was made following the methods of [16]. Each container was aerated daily for 30 minutes. The entire set-up of experiment was maintained in 12:12 h photoperiod, and $\mathrm{pH}$ of the water was ranged between 7.8 and 9.0. The water temperature was maintained at $24.5^{\circ} \mathrm{C} \pm 0.95^{\circ} \mathrm{C}$.

\subsection{Statistical Analysis}

We used ANOVA to find out the differences in chlorophyll and zooplankton productivity over the time and concentration. Karl Pearson correlation coefficient was used to find out the relationship between time and chlorophyll production over the time in each test concentration. All data of this experiment were processed using SPSS (ver 16.0).

\section{Results}

\subsection{Chlorophyll Production}

Figure 1 represents total chlorophyll production $\left(\mu \mathrm{g} \cdot \mathrm{L}^{-1}\right)$ at treatment of different concentrations of combinations of pesticides and fertilizers over a period of 42 days. The total chlorophyll production in control (Figure 1(a)) varied between 44.0 and $59.0 \mu \mathrm{g} \cdot \mathrm{L}^{-1}$ (mean $53.4 \pm 6.37 \mu \mathrm{g} \cdot \mathrm{L}^{-1}$ ) and as the time proceeds the chlorophyll production also increased $(r=0.83, p=0.042)$ however, over the study period, there was an average increase of $13.9 \mu \mathrm{g} \cdot \mathrm{L}^{-1}$. When malathion $\left(100 \mu \mathrm{g} \cdot \mathrm{L}^{-1}\right)$ is mixed with $\mathrm{NO}_{3}-\mathrm{N}\left(8 \mathrm{mg} \cdot \mathrm{L}^{-1}\right)$, and $\mathrm{PO}_{4}-\mathrm{P}\left(8 \mathrm{mg} \cdot \mathrm{L}^{-1}\right)$ there was a continuous increase in chlorophyll production over the period of experiment (time v/s production: $\mathrm{r}=0.89, \mathrm{p}=$
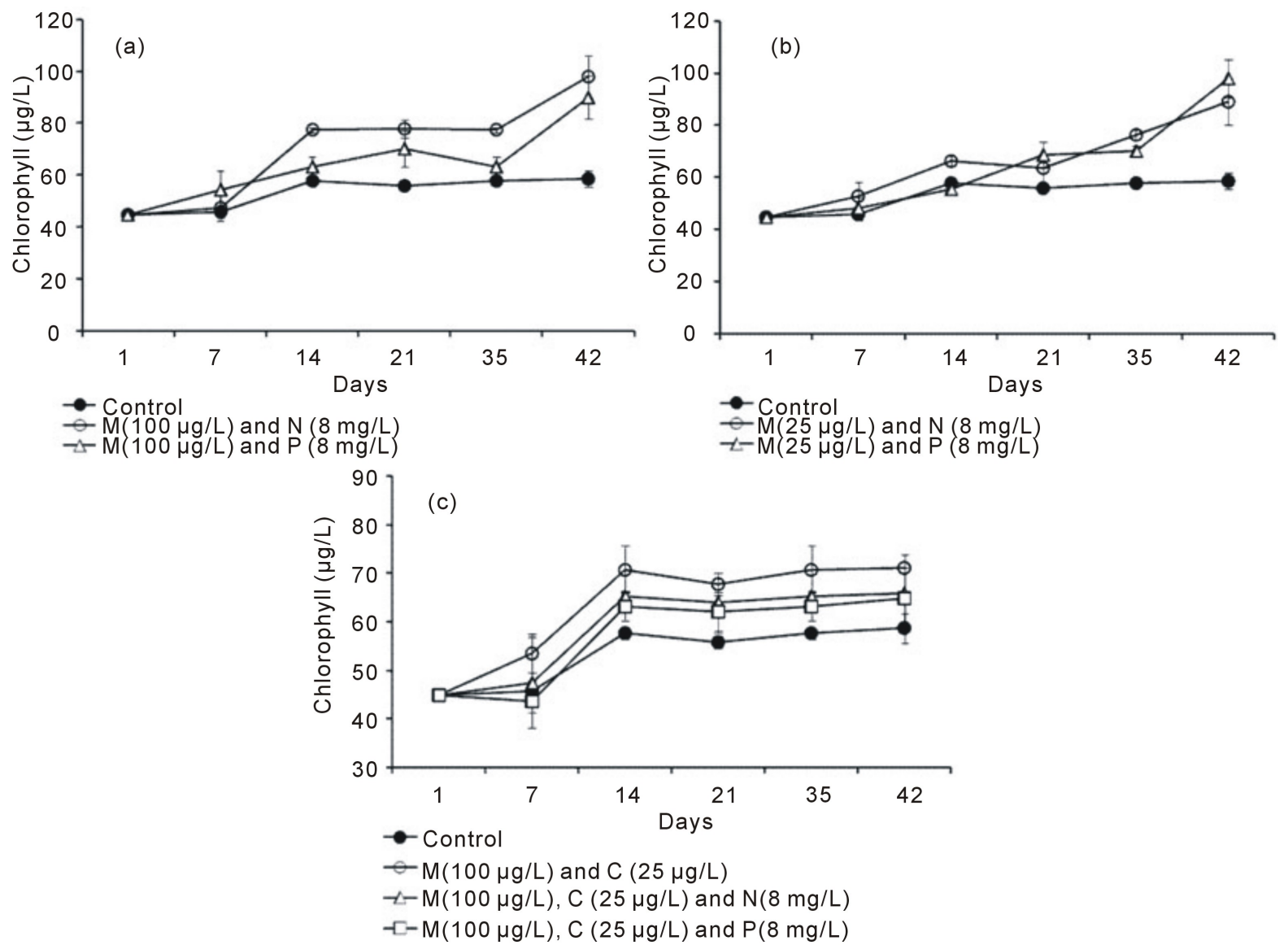

Figure 1. Chlorophyll content $\left(\mu \mathrm{g} \cdot \mathrm{L}^{-1}\right)$ recorded at different combinations of pesticide and fertilizer treatment over the time. (a)= Malathion and two fertilizer treatment; (b) = cypermethrin and two fertilizer treatment and (c) = combinations of Malathion, cypermethrin and fertilizers. In the legend, M, C, N and P refer to Malathion, cypermethrin, Nitrate-nitrogen and phosphate-phosphorus respectively. 
0.016 and $r=0.87,0.025$ respectively). Further, combination of Nitrate and Phosphate with malathion showed the high productivity ( $25 \%$ and $17 \%$ respectively) compared to control and is statistically significant $\left(F_{2,15}=\right.$ 12.766, $\mathrm{p}=0.001)$.

A similar trend (Figure 1(b)) of increased productivity over time compared to control is apparent with the combinations of cypermethrin $\left(25 \mu \mathrm{g} \cdot \mathrm{L}^{-1}\right)$ and $\mathrm{NO}_{3}-\mathrm{N}$, and $\mathrm{PO}_{4}-\mathrm{P}\left(8 \mathrm{mg} \cdot \mathrm{L}^{-1}\right.$ each) (control; $\mathrm{r}=0.83$, $\mathrm{p}=0.042$; with $\mathrm{NO}_{3}-\mathrm{N}, \mathrm{r}=0.97, \mathrm{p}=0.001$ and with $\left.\mathrm{PO}_{4}-\mathrm{P}, \mathrm{r}=0.94, \mathrm{p}=0.005\right)$. But the magnitude of increase in chlorophyll productivity is slightly low (with $\mathrm{NO}_{3}-\mathrm{N}=7 \%$ and with $\mathrm{PO}_{4}-\mathrm{P}=1 \%$ ) compared to combination of same fertilizers with malathion. The overall increase in productivity in these two combinations was $19 \%$ and $16.8 \%$ compared to control. This difference in increased productivity is highly significant $\left(F_{2,15}=11.57, \mathrm{p}=0.001\right)$

In case of two pesticides combinations (malathion $100 \mu \mathrm{g} \cdot \mathrm{L}^{-1}$ and cypermethrin $25 \mu \mathrm{g} \cdot \mathrm{L}^{-1}$ ) (Figure $1(\mathrm{c})$ ), the chlorophyll production was high compared to control and differences are not significant $\left(F_{2,10}=3.41, \mathrm{p}=0.094\right)$. Similarly two pesticides with $\mathrm{NO}_{3}-\mathrm{N}$ and $\mathrm{PO}_{4}-\mathrm{P}$ showed slightly high chlorophyll production compared to control (average 15.3\%, 6.3\% and 9.2\% respectively). The mean chlorophyll production in case of two pesticide alone was found to be $63.1 \pm 11.23 \mu \mathrm{g} \cdot \mathrm{L}^{-1}$, while combinations of these two pesticide with nitrate was $58.8 \pm$ $9.83 \mu \mathrm{g} \cdot \mathrm{L}^{-1}$ and that of combination with phosphate was $57.0 \pm 9.74 \mu \mathrm{g} \cdot \mathrm{L}^{-1}$.

\subsection{Zooplankton Density and Diversity}

In control, over the period of experiment, the diversity remained high (15 - 19 species) and did not fluctuate considerably, while the density (ind. $\mathrm{L}^{-1}$ ) was high (range: $43-69$ ind. $\mathrm{L}^{-1}$ ) with a trend till $21^{\text {st }}$ day and thereafter it reduced between 21 and 28/L (Figure 2(a)). In all treatment groups, both density and diversity decreased drastically over a period of time. Combinations of malathion with both fertilizers, combination of both pesticides with two fertilizers showed similar trend of density and diversity (Figures 2(b)-(d)).

\subsection{Relation between Chlorophyll Production and Zooplankton}

Table 1 details the mean chlorophyll concentration $\left(\mu \mathrm{g} \cdot \mathrm{L}^{-1}\right)$ with concurrent density of zooplankton $\left(\right.$ Nos $\left.\mathrm{L}^{-1}\right)$ and ratio between two in different treatment groups recorded at the end of the experiment. The average production of chlorophyll in all treatment groups are more than control group. The zooplankton density remained high in control and reduced to minimum of 5ind/L in combinations of two pesticides and fertilizers, concurrently diversity of zooplankton have also reduced from 18 (control) to 6 respectively. Compared to control, the zooplankton-chlorophyll ratio was high in combinations of two pesticides (89\%) and low in malathion with nitrate-nitrogen and Phosphate-phosphorus.

\section{Discussion}

Recent studies showed the occurrence of pesticides and other agrochemicals and their residues in surface water and groundwater near agriculture lands over the world [17] [18]. These compounds mainly comprise pesticides used on agriculture crops. Impacts of chemical contaminants on natural communities are important as they affect ecosystem dynamics [19]. In aquatic systems, pesticides and fertilizers are common type of contaminant, however understanding the effects of pesticide mixtures and fertilizers on aquatic organisms is still in its early stages [20]. A few recent studies reveled that combinations of pesticides can have dramatic direct and indirect effect on aquatic communities especially on the zooplankton. Such studies conducted by Relyea [8] have showed that cocktail of pesticide affect zooplankton, phytoplankton, and periphyton and non-target species of vertebrates. Insecticides which contaminate water bodies may severely affect the zooplankton population [1]. In Western Ghats of India, many intermittent ponds in agriculture landscape where different pesticides and fertilizers are being used have showed algal bloom and low lower-invertebrate diversity. Further, large agriculture landscapes are made into small plots of different crop systems, and each is owned by different farmers who use different agrochemicals. Further, not many of the farmer use considerable amount of agrochemicals, but most of the water bodies in these agro-ecosystems showed eutrophication. Therefore, in our study, we made an attempt to understand impact of realistic concentrations of two commonly used pesticides and fertilizers on the aquatic productivity and zooplankton. The concentrations of pesticides and fertilizers we used in this experiment were frequently found in rice paddy field water immediately after application of pesticides and fertilizers.

In the present study, we found low zooplankton diversity and density when combinations of pesticides were used for treatment (Table 1). Further, if such combinations of pesticides are mixed with fertilisers, then also 

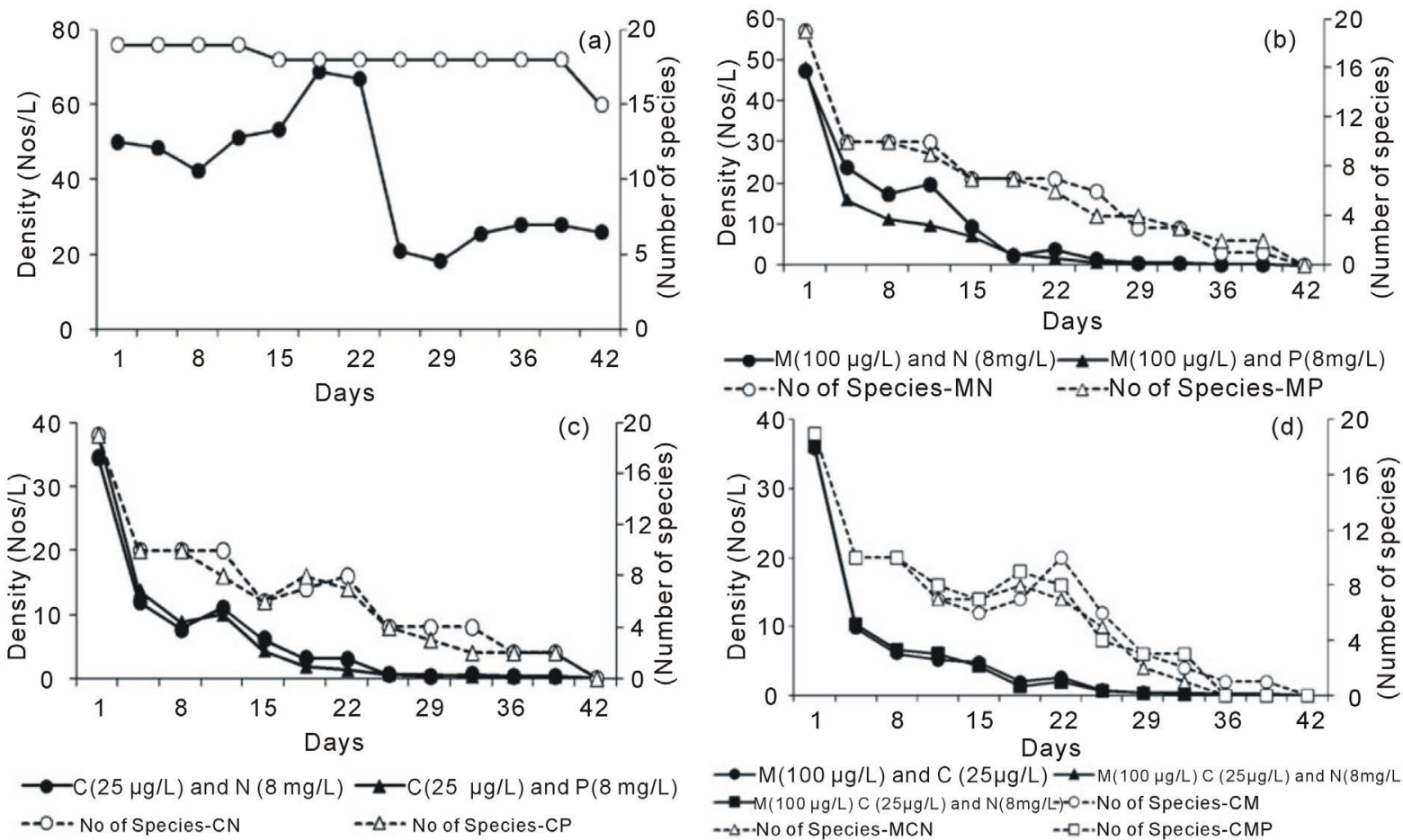

$\rightarrow-M(100 \mu \mathrm{g} / \mathrm{L})$ and $\mathrm{C}(25 \mu \mathrm{g} / \mathrm{L}) \rightarrow \mathrm{M}(100 \mu \mathrm{g} / \mathrm{L}) \mathrm{C}(25 \mu \mathrm{g} / \mathrm{L})$ and $\mathrm{N}(8 \mathrm{mg} / \mathrm{L})$ $\rightarrow-M(100 \mu \mathrm{g} / \mathrm{L}) \mathrm{C}(25 \mu \mathrm{g} / \mathrm{L})$ and $\mathrm{N}(8 \mathrm{mg} / \mathrm{L})-\mathrm{O}-\mathrm{-}$ No of Species-CM $-\because \Delta-\cdot$ No of Species-MCN $\quad-\square-\cdot$ No of Species-CMP

Figure 2. Density (Average Nos $\mathrm{L}^{-1}$ ) and diversity (total diversity) of zooplankton at different concentrations of pesticides and fertilizers over the period of experiment. (a)= control; (b) = Malathion $\left(100 \mu \mathrm{g} \cdot \mathrm{L}^{-1}\right)$ with $\mathrm{NO}_{3}-\mathrm{N}\left(8 \mathrm{mg} \cdot \mathrm{L}^{-1}\right)$ and $\mathrm{PO}_{4}-\mathrm{P}$ $\left(8 \mathrm{mg} \cdot \mathrm{L}^{-1}\right)$ treatment; (c) = Cypermethrin $\left(25 \mu \mathrm{g} \cdot \mathrm{L}^{-1}\right)$ with $\mathrm{NO}_{3}-\mathrm{N}\left(8 \mathrm{mg} \cdot \mathrm{L}^{-1}\right)$ and $\mathrm{PO}_{4}-\mathrm{P}\left(8 \mathrm{mg} \cdot \mathrm{L}^{-1}\right)$ treatment; (d) $=$ Combinations of Pesticides and fertilizers (malathion; $100 \mu \mathrm{g} \cdot \mathrm{L}^{-1}$ and cypermethrin; $25 \mu \mathrm{g} \cdot \mathrm{L}^{-1}$ alone and with $\mathrm{NO}_{3}-\mathrm{N}(8$ $\left.\mathrm{mg} \cdot \mathrm{L}^{-1}\right)$ and $\mathrm{PO}_{4}-\mathrm{P}\left(8 \mathrm{mg} \cdot \mathrm{L}^{-1}\right)$ treatment $)$. In the legend, $\mathrm{M}, \mathrm{C}, \mathrm{N}$ and $\mathrm{P}$ refer to Malathion, Cypermethrin, Nitrate-nitrogen and Phosphate-phosphorus respectively..

Table 1. Mean chlorophyll content, zooplankton density and zooplankton-chlorophyll ratio at different treatment and control groups as recorded at the end of the experiment.

\begin{tabular}{|c|c|c|c|c|}
\hline Treatment & $\begin{array}{l}\text { Chlorophyll } \\
\text { Concentration } \\
\left.\left(\mu \mathrm{g} \cdot \mathrm{L}^{-1}\right)\right)\end{array}$ & $\begin{array}{l}\text { Zooplankton } \\
\text { density } \\
\left.\text { (ind. } L^{-1}\right) \text { ) }\end{array}$ & $\begin{array}{l}\text { Zooplankton- } \\
\text { Chlorophyll ratio }\end{array}$ & $\begin{array}{l}\text { Average diversity } \\
\text { of Zooplankton }\end{array}$ \\
\hline Control & $53.4 \pm 6.37$ & $41 \pm 5.6$ & 76.2 & 18 \\
\hline Malathion $\left(100 \mu \mathrm{g} \cdot \mathrm{L}^{-1}\right)+\mathrm{NO}_{3}-\mathrm{N}\left(8 \mathrm{mg} \cdot \mathrm{L}^{-1}\right)$ & $70.5 \pm 20.47$ & $10 \pm 4.6$ & 13.8 & 7 \\
\hline Malathion $\left(100 \mu \mathrm{g} \cdot \mathrm{L}^{-1}\right)+\mathrm{PO}_{4}-\mathrm{P}\left(8 \mathrm{mg} \cdot \mathrm{L}^{-1}\right)$ & $64.3 \pm 15.34$ & $8 \pm 4.3$ & 11.9 & 7 \\
\hline Cypermethrin $\left(25 \mu \mathrm{g} \cdot \mathrm{L}^{-1}\right)+\mathrm{NO}_{3}-\mathrm{N}\left(8 \mathrm{mg} \cdot \mathrm{L}^{-1}\right)$ & $65.4 \pm 15.94$ & $6 \pm 3.1$ & 9.4 & 7 \\
\hline Cypermethrin $\left(25 \mu \mathrm{g} \cdot \mathrm{L}^{-1}\right)+\mathrm{PO}_{4}-\mathrm{P}\left(8 \mathrm{mg} \cdot \mathrm{L}^{-1}\right)$ & $64.2 \pm 19.55$ & $6 \pm 3.5$ & 9.6 & 7 \\
\hline Malathion $\left(100 \mu \mathrm{g} \cdot \mathrm{L}^{-1}\right)+$ Cypermethrin $\left.\left(25 \mu \mathrm{g} \cdot \mathrm{L}^{-1}\right)\right)$ & $63.1 \pm 11.21$ & $5 \pm 3.2$ & 8.4 & 6 \\
\hline $\begin{array}{c}\text { Malathion }\left(100 \mu \mathrm{\mu g} \cdot \mathrm{L}^{-1}\right)+\text { Cypermethrin }\left(25 \mu \mathrm{g} \cdot \mathrm{L}^{-1}\right)+ \\
\mathrm{PO}_{4}-\mathrm{P}\left(8 \mathrm{mg} \cdot \mathrm{L}^{-1}\right)\end{array}$ & $56.9 \pm 9.91$ & $5 \pm 3.1$ & 9.2 & 6 \\
\hline $\begin{array}{c}\text { Malathion }\left(100 \mu \mathrm{g} \cdot \mathrm{L}^{-1}\right)+\text { Cypermethrin }\left(25 \mu \mathrm{g} \cdot \mathrm{L}^{-1}\right)+ \\
\mathrm{NO}_{3}-\mathrm{N}\left(8 \mathrm{mg} \cdot \mathrm{L}^{-1}\right)\end{array}$ & $58.8 \pm 9.83$ & $5 \pm 3.2$ & 8.9 & 6 \\
\hline
\end{tabular}

similar effect with increased chlorophyll concentration was noticed. It has been found that isolated ecosystems were more susceptible to damage caused by pesticides and community structure changed to lower biodiversity states [21].

Pesticides are known to cause a selective toxicity which in turn reduces green algae and promotes blue green algae, concurrently reduces invertebrates that graze on algae. The selective effect pesticides on blue green algae also cause recruitment of algal grazer in the rice fields. Thereby, pesticide application usually caused a decrease in other populations followed by proliferation of primary consumers Ostracods, Chironomid and mosquito lar- 
vae, and molluscs [22] [23]. In the present study, we found that six species of zooplankton belonging to ostracods as survivors in all treatment group and these species appears to be such pesticides being used in this region.

Results of our study revealed that, chlorophyll production was supported by addition of fertilizers, while combinations of fertilizers with either one or two pesticides reduced the zooplankton density and diversity rendering chlorophyll concentration more than control ones. This could be an indicative of eutrophication of ponds located in agro-ecosystems. The results of this study demonstrate that a single application of combinations of pesticides (in spite of presence of fertilizers) even at low concentrations can produce severe effects on several taxonomic groups such as zooplankton of pond ecosystem and can change the health of water bodies located in agro-ecosystems.

\section{References}

[1] T. Hanazato (2001) Pesticide Effects on Freshwater Zooplankton: An Ecological Perspective. Environmental Pollution, 112, 1-10. http://dx.doi.org/10.1016/S0269-7491(00)00110-X

[2] S.K. Jalali, S.P. Singh, T. Venkatesan, K.S. Murthy and Y. Lalita (2006) Development of Endosulfan Tolerant Strains of an Egg Parasitoid Trichogramma chilonis. Indian Journal of Experimental Biology, 44, 584-590.

[3] R. Schwarenbach, B.J. Escher, K. Fenner, T.B. Hoffstetter, C.A. Jonson and U. Von Gunten (2006) The Challenge of Micropollutants in Aquatic Systems. Science, 313, 1072-1077. http://dx.doi.org/10.1126/science.1127291

[4] J.A. Wyman, J.O. Jensen, D. Curwen, R.L. Jones and T. E. Marquardt (1985) Effects of Application Procedures and Irrigation on Degradation and Movement of Aldicarb Residues in Soil. Environmental Toxicology and Chemistry, 4, 641-651. http://dx.doi.org/10.1002/etc.5620040508

[5] R. P. Richards and D. B. Baker (1993) Pesticide Concentration Patterns in Agricultural Drainage Networks in the Lake Erie Basin. Environmental Toxicology and Chemistry, 12, 13-26. http://dx.doi.org/10.1002/etc.5620120104

[6] R.A. Relyea and T.H. Jason (2008) Interactive Effects of Predators and a Pesticide On Aquatic Communities. Oikos, 117, 1647-1658. http://dx.doi.org/10.1111/j.1600-0706.2008.16933.x

[7] R. A. Relyea (2005) The Impact of Insecticides and Herbicides on the Biodiversity and Productivity of Aquatic Communities. Ecological Applications, 15, 618-627. http://dx.doi.org/10.1890/03-5342

[8] R. A. Relyea (2009) A Cocktail of Contaminants: How Mixtures of pesticides at low concentrations Affect Aquatic Communities. Oecologia, 159, 363-376. http://dx.doi.org/10.1007/s00442-008-1213-9

[9] P. A. Roger, I. Simpson, R. Oficialc, S. Ardales and R. Jimenez (1994) Effects of Pesticides on Soil and Water Microflora and Mesofauna in Wetland Ricefields: A Summary of Current Knowledge and Extrapolation to Temperate Environments. Australian Journal of Experimental Agriculture, 34, 1057-1068. http://dx.doi.org/10.1071/EA9941057

[10] J. H. Cathleen, P. D. Christopher, V. Z. Paul, and L. M. Laura (2002) Agrochemical and Nutrient Impacts on Estuaries and Other Aquatic Systems. Journal of Agricultural and Food Chemistry, 50, 4382-4384. http://dx.doi.org/10.1021/jf020457n

[11] K. Vijayavel, S. Ezhilarasibalasubramanian and M. P. Balasubramanian (2006) Individual and Combined Effect of Urea and Ammonium Chloride on Aspartate and Alanine Transaminases of a Fresh Water Fish Oreochromis mossambicus. Indian Journal of Fisheries, 53, 19-22.

[12] K. Y. Surendra (2010) Pesticide Applications-Threat to Ecosystems. Journal of Human Ecology, 32, 37-45.

[13] H.P. Gurushankara, S.V. Krishnamurthy and V. Vasudev (2007) Effect of Malathion on Survival, Growth and Food Consumption of Indian Cricket Frog (Limnonectus limnocharis) Tadpoles. Archives of Environmental Contamination and Toxicology, 52, 251-256. http://dx.doi.org/10.1007/s00244-006-0015-5

[14] M.B. Nataraj and S.V. Krishnamurthy (2012) Effects of Combinations of Malathion and Cypermethrin on Survivability and Time of Metamorphosis of Tadpoles of Indian Cricket Frog (Fejervarya limnocharis). Environmental Science and Health, Part B, 47, 67-73. http://dx.doi.org/10.1080/03601234.2012.611428

[15] W.T. Edmonson (1959) Fresh-Water Biology. 2nd Edition, John Wiley and Sons, New York, 1248.

[16] Parsons, T.T. and Strickland, J.D.H. (1963) Discussion of Spectrophotometric Determination of Marine-Plant Pigments, with Revised Equations for Ascertaining Chlorophylls and Carotenoids. Journal of Marine Research, 21, 155-163.

[17] Woudneh, M.B., Ou, Z., Sekela, M., Tuominen, T. and Gledhill, M. (2009) Pesticide Multiresidues in Waters of the Lower Fraser Valley, British Columbia, Canada. Part I. Surface Water. Journal of Environnemental Quality, 38, 940947. http://dx.doi.org/10.2134/jeq2007.0524

[18] Añasco, N., Uno, S., Koyama, J., Matsuoka, T. and Kuwahara, N. (2010) Assessment of Pesticide Residues in Freshwater Areas Affected by Rice Paddy Effluents in Southern Japan. Environmental Monitoring and Assessment, 160, 371-383. http://dx.doi.org/10.1007/s10661-008-0701-z 
[19] Relyea, R.A. and Hoverman, J.T. (2006) Assesing the Ecology in Ecotoxicology: A Review and Synthesis in Freshwater Systems. Ecology Letters, 9, 1157-1171. http://dx.doi.org/10.1111/j.1461-0248.2006.00966.x

[20] Krishnamurthy, S.V. and Smith, G.R. (2011) Combined Effects of Malathion and Nitrate on Early Growth, Abnormalities, and Mortality of Wood Frog (Rana sylvatica) Tadpoles. Ecotoxicology, 20, 1361-1367. http://dx.doi.org/10.1007/s10646-011-0692-3

[21] Hanson, M.L., Graham, D.W., Babin, E., Azam, D., Coutellec, M.A., Knapp, C.W., Lagadic, L. and Caquet, T. (2007) Influence of Isolation on the Recovery of Pond Mesocosms from the Application of an Insecticide. I. Study Design and Planktonic Community Responses. Environmental Toxicology and Chemistry, 26, 1265-1279. http://www.ncbi.nlm.nih.gov/pubmed/17571694 http://dx.doi.org/10.1897/06-248R.1

[22] Ishibashi, N. and Ito, S. (1981) Effects of Herbicide Benthiocarb on Fauna in Paddy Field (Jpn). Proceedings of the Association for Plant Protection, Kyushu, 27, 90-93. http://dx.doi.org/10.4241/kyubyochu.27.90

[23] Roger, P.A. and Kurihara, Y. (1988) Floodwater Biology of Tropical Wetland Ricefields. Proceedings of the 1st International Symposium on Paddy Soil Fertility, ChiangMai, 6-13 December 1988, 275-300. 